How to cite this article:

Mohamad, N. A., Ismail, A., \& Mohd Shariff, M. N. (2019). Motivasi pembelajaran sebagai pemboleh ubah pengantara dalam perhubungan antara bimbingan penyelia dengan motivasi kerja. International Journal of Management Studies, 26(2), 99-124.

\title{
MOTIVASI PEMBELAJARAN SEBAGAI PEMBOLEH UBAH PENGANTARA DALAM PERHUBUNGAN ANTARA BIMBINGAN PENYELIA DENGAN MOTIVASI KERJA \\ (Learning Motivation as a Mediating Variable in the Relationship Between Supervisory Guidance and Job Motivation)
}

\author{
NUR IZZATY MOHAMAD \\ Institut Islam Hadhari \\ Universiti Kebangsaan Malaysia
}

AZMAN ISMAIL

Faculty of Economics \& Management

Universiti Kebangsaan Malaysia

MOHD NOOR MOHD SHARIFF

Pusat Pengajian Pengurusan Perniagaan

Universiti Utara Malaysia

*Corresponding author: nurizzaty_mohamad@yahoo.com

\begin{abstract}
Abstrak
Tujuan kajian ini adalah untuk menilai perhubungan antara bimbingan penyelia, motivasi pembelajaran dan motivasi kerja. Borang soal selidik telah digunakan untuk mengumpul data daripada pekerja di Agensi-agensi Pusat Kerajaan Persekutuan Malaysia, Putrajaya. Perisian SmartPLS telah digunakan untuk menilai kualiti data borang soal selidik dan menguji hipotesis-hipotesis kajian. Keputusan analisis model laluan SmartPLS menunjukkan bahawa kesan bimbingan penyelia terhadap motivasi kerja
\end{abstract}


dipengaruhi secara tidak langsung oleh motivasi pembelajaran. Dapatan kajian ini menerangkan bahawa keupayaan penyelia mengamalkan bimbingan secara teratur dalam melaksanakan operasi kerja harian dapat membangkitkan motivasi pembelajaran dalam diri pekerja. Natijahnya, motivasi ini boleh pula mendorong mereka meningkatkan motivasi kerja. Dapatan kajian ini boleh digunakan sebagai panduan oleh pengamal untuk memahami kerumitan konsep motivasi pembelajaran dan merangka pelan tindakan strategi untuk meningkatkan kemahiran kejurulatihan kepimpinan bagi mencapai dan mengekalkan matlamat dan strategi organisasi dalam era globalisasi dan ekonomi berasaskan pengetahuan.

Kata Kunci: Bimbingan penyelia, motivasi pembelajaran, motivasi kerja, SmartPLS.

\begin{abstract}
The aim of this study is to assess the relationship between supervisors' coach, learning motivation and job motivation. Survey questionnaires were used to collect data from employees at Malaysian Federal Government Central Agencies, Putrajaya. The SmartPLS was utilised to evaluate the quality of survey questionnaire data and hence test theresearch hypotheses. The outcomes of SmartPLS path model analysis display that effect of supervisors' coach on job motivation has indirectly been affected by learning motivation. This outcome explains that the ability of supervisors to appropriately implement coaching in executing daily job operations had strongly invoked employees' learning motivation. As a result, this motivation could lead to a higher job motivation. Further, this outcome may be used as a useful guideline to assist practitioners in upgrading their understanding of the complexity of learning motivation concept and draw strategic action plans to strengthen managerial coaching in maintaining and enhancing the organisational strategies and objectives in an era of globalisation and knowledge based economy.
\end{abstract}

Keywords: Supervisors' coach, learning motivation, work motivation, SmartPLS.

Received: 16/12/2019 Revised: 11/4/2020 Accepted: 12/4/2020 Published: 25/6/2020

\title{
Pengenalan
}

Perkembangan global yang tidak terkawal dan berlaku di luar jangkaan ialah pencetus utama kepada transformasi organisasi. 
Transformasi ini biasanya dilaksanakan secara instrumental (seperti pembaharuan skop dan prosedur kerja) dan komprehensif (seperti penstrukturan organisasi) bagi membantu organisasi meningkatkan daya saing, menguasai pasaran saham dan mengekalkan prestasi dalam ekonomi global (Abdullah Lin, Gunalan Nadarajah, Mohmad Yazam Sharif, Abul Bashar Bhuiyan, Md. Aminul Islam, 2015; Ospina, Hadidy \& Caisedo, 2011; Portefrect, 2019). Selari dengan transformasi organisasi, majikan telah memberi kuasa autonomi pengstafan kepada jabatan pengurusan sumber manusia untuk mengurus program latihan kepada pekerja yang berkhidmat dalam pelbagai peringkat dan kategori jawatan (Turner \& Baker, 2017; Roblek, Erenda \& Mesko, 2018).

Organisasi yang berjaya menyedari kepentingan program latihan dan sanggup menyediakan peruntukan yang sangat besar bagi mencapai objektif mereka dalam era persaingan global. Sebagai contoh, menurut Analisis Biro Ekonomi Amerika Syarikat mendedahkan bahawa sebanyak \$366 bilion telah diperuntukkan oleh organisasi besar untuk merangka dan membangunkan program latihan bagi menambah baik keadaan dan struktur pengetahuan dan kemahiran dalam membina kerjaya pekerja. Keadaan ini menggambarkan peratusan perbelanjaan organisasi yang tertinggi iaitu 18 peratus dalam tempoh lima tahun berturut-turut (Pontefract, 2019). Manakala, mengikut Laporan Industri Latihan tahun 2018 menunjukkan bahawa sebanyak $\$ 87.6$ bilion pelaburan latihan telah diperuntukkan kepada tiga jenis perbelanjaan, iaitu USD $\$ 11$ bilion untuk perbelanjaan peralatan dan perkhidmatan luar (contohnya e-learning, penginapan), USD\$29.6 bilion untuk perbelanjaan latihan (contohnya, elaun perjalanan) dan USD $\$ 47$ bilion untuk penyedia latihan (contohnya, kakitangan dalaman, freelancers, pembekal) (Pontefract, 2019). Pelaburan sangat besar ini amat berguna untuk mendedahkan pekerja terhadap pengetahuan yang penting, kemahiran terkini, kebolehan kognitif dan emosi yang baharu, sikap yang positif dan kebolehan semasa bagi membantu meningkatkan dan mengekalkan daya saing organisasi dan menguasai pasaran saham dalam ekonomi global (Lee, Park \& Bakers, 2017; Turner \& Baker, 2017; Roblek, Erenda \& Mesko, 2018).

Dalam organisasi yang berjaya, jabatan sumber manusia sering kali bekerjasama dengan jabatan-jabatan yang lain dan mempelawa perunding-perunding profesional untuk mereka bentuk dan 
melaksanakan program pembelajaran organisasi yang terancang. Antara program pembelajaran organisasi yang biasa dilaksanakan ialah latihan di tempat kerja (seperti kursus pendek dalam perkhidmatan bagi tujuan meningkatkan kecekapan kerja dan pengesahan jawatan) dan latihan di luar tempat kerja (seperti seminar dan bengkel anjuran luar dan kolaborasi pendidikan dengan institusi pengajian tinggi) (Govaerts, Eva \& Filip, 2017; Lee et al., 2017). Keduadua jenis latihan ini berbeza dari segi kandungan dan prosedur, tetapi ia saling melengkapi dan boleh bekerjasama untuk membantu pekerja meningkatkan pengetahuan yang penting, kemahiran yang terkini, kebolehan kognitif dan emosi yang baharu, sikap yang positif dan kompetensi yang sesuai dengan era revolusi industri 4.0. Seterusnya, keadaan ini dapat mencapai dan mengekalkan misi dan wawasan perniagaan organisasi dalam era persaingan global (El Hajjar \& Alkhanaizi, 2018; Turner \& Baker, 2017).

Penelitian yang mendalam terhadap kajian literatur yang berkaitan dengan latihan organisasi mendapati bahawa sungguhpun program latihan direka dengan terancang ia tidak akan berjaya untuk mencapai objektif sekiranya penyelia tidak mempunyai kompetensi yang mencukupi untuk membimbing pekerja dengan teratur (Abdullah Lin et al., 2015; Lee et al., 2017; Turner \& Baker, 2017). Menurut Govaerts et al. (2017); Kim, Park dan Kang (2019) menjelaskan bimbingan penyelia mempunyai dua dimensi penting iaitu tunjuk ajar dan maklum balas. Tunjuk ajar biasanya dikaitkan dengan keupayaan penyelia untuk memberikan pertolongan, membincangkan kaedah kerja, memberi khidmat nasihat dan menyediakan peluang tugasan (Govaerts et al., 2017; Kim, Park \& Kang 2019). Maklum balas pula kerap kali dirujuk sebagai keupayaan penyelia untuk melaporkan prestasi kerja terkini, memberikan pandangan yang positif dan menyampaikan idea penambahbaikan. Kedua-dua jenis bimbingan tersebut adalah sangat penting dalam mendorong pekerja untuk mencapai dan mengekalkan sasaran kerja tahunan (Kim et al., 2019; Lee et al., 2017; Govaerts et al., 2017).

Kajian yang dilaksanakan baru-baru ini mendapati bahawa bimbingan penyelia telah dilihat sebagai isu yang sangat kritikal dalam organisasi yang berjaya. Sebagai contoh, menurut kajian oleh Schindler dan Bukholder (2014) serta Govaerts et al. (2017) membuktikan bahawa keupayaan penyelia mengamalkan bimbingan secara teratur dalam 
melaksanakan operasi kerja harian dapat memberi impak kepada sikap pekerja yang positif, terutamanya motivasi kerja (Utrilla, Grande \& Lorenzo, 2012; Nadeem \& Ahmad, 2017; Park, Kang \& Kim, 2018) dan motivasi pembelajaran (Abu Alsondos, Panggil \& Othman, 2015; Govaerts et al., 2017; Park et al., 2018). Dalam perspektif gelagat organisasi, motivasi kerja sering kali ditakrifkan sebagai ciri-ciri intrinsik (seperti keinginan dan keperluan) dan ciriciri ekstrinsik (seperti menyedari hasil usaha) adalah dua pendorong utama yang menggerakkan pekerja untuk melaksanakan tugasan hakiki (seperti deskripsi kerja yang ditetapkan mengikut jawatan) dan bukan hakiki (seperti menolong rakan sejawat menyelesaikan tugas harian) (Kanfer, Frese \& Johnson, 2017; Hee \& Rhung, 2019). Tahap motivasi ini boleh mempengaruhi pekerja untuk menguruskan tugasan secara teratur bagi mencapai sasaran kerja tahunan (Kim \& Kuo, 2015; Kim et al., 2019). Sementara itu, motivasi pembelajaran pula biasanya ditakrifkan sebagai kemahuan dan kesanggupan yang wujud dalam diri pekerja untuk menghadiri dan mempelajari kandungan latihan (seperti objektif, kebolehan berucap, kemahiran teknikal, pembangunan kerja berkumpulan dan berfikir secara kritis) dalam program latihan di tempat kerja dan di luar tempat kerja (Kanfer, Frese \& Johnson, 2017; Hee \& Rhung, 2019). Penguasaan kompetensi tersebut dapat digunakan untuk menyelesaikan masalah kerja harian, meningkatkan prestasi kerja harian dan melaksanakan perancangan taktikal dan strategi organisasi (Abu Alsondos et al., 2015; Schindler \& Bukholder, 2014; Lee et al., 2017).

Agak mengejutkan, kebanyakan kajian tentang kepimpinan berorientasi pekerja yang diterbitkan dalam abad ke 21 mendedahkan bahawa keupayaan penyelia melaksanakan bimbingan secara teratur dapat meningkatkan motivasi pembelajaran dan keadaan ini boleh pula meningkatkan motivasi kerja (Govaerts et al., 2017; Kim et al., 2019). Sungguhpun sifat perhubungan ini telah dikaji secara meluas, namun peranan motivasi pembelajaran sebagai pemboleh ubah pengantara dalam perhubungan tersebut adalah masih kurang dibincangkan secara terperinci dalam kajian literatur latihan organisasi (Nadeem \& Ahmad, 2017; Lee et al., 2017).

Menurut kebanyakan pengkaji, keadaan ini dipengaruhi oleh beberapa faktor: Pertama, kajian terdahulu banyak mengaplikasikan pendekatan deskriptif bagi membincangkan sifat dalaman motivasi 
pembelajaran, seperti menghuraikan secara konseptual takrif, dimensi dan kepentingan motivasi pembelajaran dalam organisasi komersial dan bukan komersial (Ismail, Mohd Zainol \& Ahmad, 2016; Nadeem \& Ahmad, 2017; Lee et al., 2017). Kedua, kajian terdahulu menggunakan model kesan langsung yang hanya mengukur hubungan antara dua konstruk kajian, iaitu: a) tanggapan pekerja terhadap bimbingan penyelia; b) hubungan antara bimbingan penyelia dengan motivasi kerja; c) hubungan antara motivasi pembelajaran dengan motivasi kerja (Kim et al., 2019; Al-Eisa, Abdulla \& Alhemoud, 2009). Model kajian tersebut telah diuji dengan menggunakan analisis statistik mudah (seperti peratusan, statistik deskriptif dan statistik bivariat) dan hasil pengukurannya hanya berupaya melaporkan sifat dan darjah keteguhan korelasi antara konstruk kajian tersebut. Sebaliknya, ujian statistik tersebut tidak berupaya untuk menentukan saiz kesan dan sifat motivasi pembelajaran sebagai pemboleh ubah pengantara yang penting dalam model kajian tersebut (Kim et al., 2019; Al-Eisa, Abdulla \& Alhemoud, 2009; Ismail et al., 2016; Nadeem \& Ahmad, 2017). Natijahnya, pendekatan kajian terdahulu hanya mengemukakan perakuan-perakuan umum dan keadaan ini tidak mencukupi untuk digunakan sebagai panduan oleh pengamal (seperti majikan dan pengurusan) bagi memahami kerumitan konsep motivasi pembelajaran dan merangka amalan pembangunan modal insan berprestasi tinggi mencapai dan mengekalkan misi dan wawasan perniagaan organisasi dalam era globalisasi dan ekonomi yang sukar diramalkan.

Kajian ini menilai amalan bimbingan penyelia yang dilaksanakan dalam Agensi-agensi Pusat Kerajaan Persekutuan Malaysia. Ia merupakan gaya latihan berorientasi perhubungan manusia yang sangat penting untuk meningkatkan produktiviti berteraskan pengetahuan seperti yang disarankan dalam Rancangan Malaysia Kesebelas (RMK-11), iaitu menyampaikan perkhidmatan yang telus dan kepantasan untuk bertindak (Jabatan Perkhidmatan Awam, 2019; Pekeliling Kemajuan Pentadbiran Awam, 2018). Untuk mencapai matlamat tersebut, penyelia dilibatkan secara aktif dalam menilai keperluan latihan, menggariskan pelan operasi tahunan latihan, membuat belanjawan dan menyediakan sokongan instrumental untuk menggalakkan pekerja dapat memahirkan diri, mengembangkan pengetahuan dan mewujudkan tingkah laku positif semasa bertugas dalam organisasi (Jabatan Perkhidmatan Awam, 2019). Pendedahan 
baharu yang diperoleh penyelia dapat meningkatkan keyakinan diri mereka untuk membimbing pekerja bawahan melalui tunjuk ajar (seperti memberikan panduan, berkongsi teknik dalam tugas, memberikan khidmat nasihat) dan menyampaikan maklum balas (seperti melaporkan prestasi, membuat penilaian kompetensi latihan, menilai prestasi dengan adil) dapat mendorong pekerja meningkatkan motivasi pembelajaran (seperti knowledge sharing, buddy system) (Jabatan Perkhidmatan Awam, 2019).

Kebanyakan pekerja merasakan bahawa tahap motivasi pembelajaran mereka boleh pula membangkitkan motivasi untuk melaksanakan tugas dan tanggungjawab harian dengan bersungguh-sungguh (seperti keinginan untuk melaksanakan tugas dengan baik, menunjukkan semangat untuk berkongsi kemahiran sesama rakan sejawat, mempunyai keyakinan menggunakan pengetahuan dan kemahiran baharu bagi mencapai objektif kerja, mengutamakan keperluan dan pengharapan pelanggan dan bilangan pekerja yang dikenakan tindakan tatatertib dan disiplin semakin berkurangan) (Musa, 2020). Sungguhpun sifat perhubungan ini adalah imperatif, namun peranan motivasi pembelajaran sebagai pemboleh ubah pengantara tidak dikaji secara terperinci dalam agensi-agensi Pusat Kerajaan Persekutuan Malaysia (Ibrahim 2007; Hussein, 2009; Pekeliling Kemajuan Pentadbiran Awam, 2018). Oleh yang demikian, keadaan di atas mendorong pengkaji untuk melengkapkan kelompangan dalam kajian literatur dengan menilai peranan motivasi pembelajaran sebagai pemboleh ubah pengantara antara bimbingan penyelia dan motivasi kerja. Secara khususnya, kajian ini menilai tiga objektif utama: Pertama, mengkaji perhubungan antara bimbingan penyelia dengan motivasi kerja. Kedua, mengkaji perhubungan antara bimbingan penyelia dengan motivasi pembelajaran. Ketiga, mengkaji perhubungan antara bimbingan penyelia, motivasi pembelajaran dan motivasi kerja.

\section{Kajian Literatur dan Pembangunan Hipotesis}

\section{Hubungan antara Bimbingan Penyelia dengan Motivasi Kerja}

Pengaruh bimbingan penyelia dalam meningkatkan motivasi kerja adalah konsisten dengan saranan yang dikemukakan oleh Teori 
Pertukaran Ahli Pemimpin (Dansereau, Graen \& Haga, 1965). Teori ini mengetengahkan bahawa kualiti perhubungan yang tinggi di antara penyelia dan pekerja akan dapat dibina apabila pekerja percaya kepada kebolehan penyelia memberikan layanan yang baik, seperti menunjukkan kecekapan dalam menyelia, menghulurkan pertolongan, mengadakan perbincangan, memberi motivasi dan khidmat nasihat serta menilai prestasi dengan jujur. Aplikasi teori ini dalam program latihan menunjukkan bahawa konsep kualiti perhubungan yang tinggi di antara penyelia dan pekerja biasanya diterjemahkan sebagai bimbingan penyelia. Saranan teori ini mendapat sokongan daripada kajian literatur yang berkaitan dengan program latihan (Utrilla et al., 2012; Nadeem \& Ahmad, 2017; Park et al., 2018).

Sebagai contoh, kajian terdahulu banyak menilai aspek bimbingan penyelia dengan menggunakan sampel organisasi yang berbeza seperti persepsi 630 orang pengurus syarikat di Sepanyol (Utrilla et al., 2012), persepsi 352 orang pekerja industri perkilangan di Pakistan (Nadeem \& Ahmad, 2017) dan persepsi 227 orang pekerja dalam bidang pendidikan di Amerika Syarikat (Park et al., 2018). Dapatan kajian tersebut melaporkan bahawa keupayaan penyelia membimbing pekerja secara teratur melalui tunjuk ajar (seperti berkongsi maklumat tugas, memberikan panduan) dan maklum balas (seperti menyampaikan maklumat tentang kriteria prestasi yang dinilai dalam tugas) dapat meningkatkan motivasi kerja dalam organisasi tersebut (Utrilla et al., 2012; Nadeem \& Ahmad, 2017; Park et al., 2018). Oleh itu, hipotesis yang diuji ialah:

$\mathrm{H}_{1}$ : Bimbingan penyelia mempunyai hubungan yang positif dengan motivasi kerja.

\section{Hubungan antara Bimbingan Penyelia dengan Motivasi Pembelajaran}

Peranan bimbingan penyelia dalam mempengaruhi motivasi pembelajaran adalah selari dengan idea utama yang disarankan oleh Teori Pertukaran Sosial (Blau, 1964). Teori ini mengesyorkan bahawa peranan penyelia dalam mengurus pertukaran sosial adalah lebih penting daripada pertukaran ekonomi (material). Sebagai contoh, kesediaan penyelia menggunakan kuasa dan pengaruhnya 
untuk memberi layanan yang baik mendorong pekerja untuk bertanggungjawab membantu organisasi dan keadaan ini boleh pula mendorong pekerja mengamalkan kelakuan yang positif dalam organisasi. Aplikasi teori ini dalam program latihan menunjukkan bahawa konsep pertukaran sosial sering kali diterjemahkan sebagai bimbingan penyelia. Teori ini menerima sokongan daripada kajian literatur yang berkaitan dengan program latihan.

Sebagai contoh, kajian lepas banyak mengkaji peranan penyelia dalam pelbagai jenis organisasi, seperti persepsi 111 orang peserta latihan di Belgium (Govaerts et al., 2017) dan persepsi 227 orang pekerja dalam bidang pendidikan di Midwest dan Amerika Syarikat (Park et al., 2018). Dapatan kajian ini menegaskan bahawa keupayaan penyelia membimbing pekerja secara teratur melalui tunjuk ajar (seperti menunjukkan garis panduan tugas, memberikan khidmat nasihat) dan maklum balas (seperti menilai prestasi dengan adil, mencatatkan komen yang membina) dapat meningkatkan motivasi pembelajaran dalam organisasi berkenaan (Govaerts et al., 2017; Park et al., 2018). Oleh itu, hipotesis yang diuji ialah:

$\mathrm{H}_{2}$ : Bimbingan penyelia mempunyai hubungan yang positif dengan motivasi pembelajaran.

\section{Hubungan antara Bimbingan Penyelia, Motivasi Pembelajaran dengan Motivasi Kerja}

Peranan motivasi pembelajaran dalam mempengaruhi perhubungan antara bimbingan penyelia dan motivasi kerja adalah bertepatan dengan maksud Teori Pembelajaran Sosial (Bandura, 1979). Teori ini menerangkan bahawa keyakinan diri seseorang ialah manifestasi daripada pemerhatian terhadap contoh teladan yang ditunjukkan oleh individu yang berjaya dan keadaan ini boleh mendorong individu tersebut melaksanakan tugas pada masa dan situasi yang tertentu. Pengaplikasian teori ini dalam program latihan menyarankan bahawa keyakinan kendiri biasanya diterjemahkan sebagai motivasi pembelajaran. Peranannya sebagai pemboleh ubah pengantara dalam perhubungan antara bimbingan penyelia dengan motivasi kerja telah mendapat sokongan yang kuat daripada kajian literatur yang berkaitan dengan program latihan. 
Sebagai contoh, beberapa kajian baharu telah dilaksanakan dalam organisasi yang berbeza-beza menggunakan saiz sampel yang berlainan, seperti tanggapan 58 orang responden dalam organisasi pendidikan (Schindler \& Bukholder, 2014) dan tanggapan 227 orang guru sekolah menengah yang terlibat dalam program latihan lintas budaya di Midwest, Amerika Syarikat (Kim et al., 2019). Dapatan kajian ini melaporkan bahawa keupayaan penyelia mengamalkan bimbingan secara teratur melalui tunjuk ajar (seperti, komunikasi, kerja berpasukan dan memberikan peluang) dan maklum balas (seperti memberikan idea, memaklumkan prestasi dan memberikan komen positif) dapat meningkatkan motivasi pembelajaran pekerja. Natijahnya, keadaan ini boleh pula meningkatkan motivasi kerja dalam organisasi tersebut (Schindler \& Bukholder, 2014; Kim et al., 2019). Oleh itu, hipotesis yang diuji ialah:

$\mathrm{H}_{3}$ : Motivasi pembelajaran berperanan sebagai pemboleh ubah pengantara dalam hubungan antara bimbingan penyelia dengan motivasi kerja.

\section{Kerangka Kajian dan Hipotesis Kajian}

Kajian literatur telah digunakan untuk membina kerangka kajian ini. Rajah 1 menunjukkan bimbingan penyelia adalah pemboleh ubah tidak bersandar, motivasi pembelajaran adalah pemboleh ubah pengantara dan motivasi kerja adalah pemboleh ubah bersandar. Rajah 1 menerangkan bahawa kesan bimbingan penyelia ke atas motivasi kerja adalah dipengaruhi secara tidak langsung oleh motivasi pembelajaran.

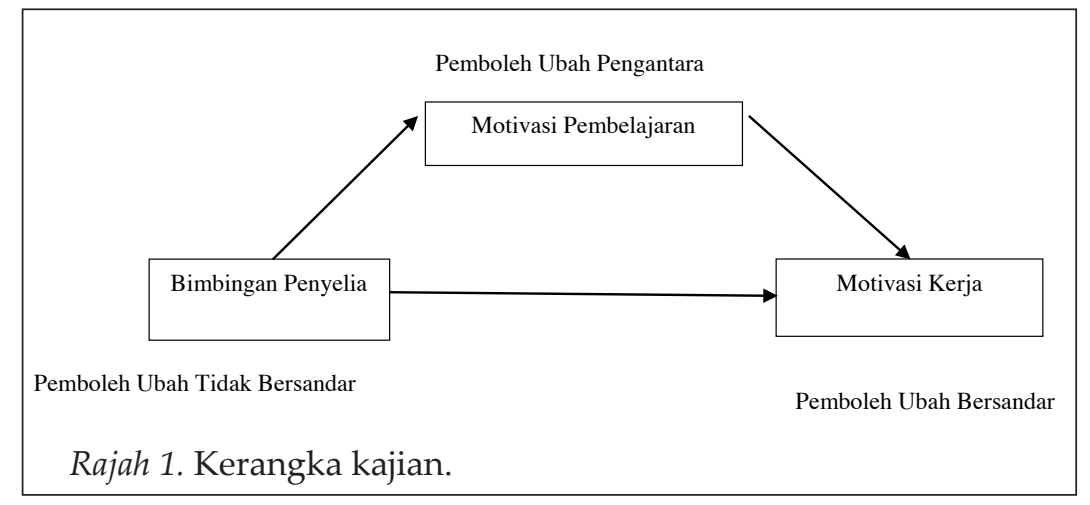




\section{Metodologi Kajian}

\section{Reka Bentuk Kajian}

Kajian ini dijalankan di Agensi-agensi Pusat Kerajaan Persekutuan Malaysia, Putrajaya. Agensi-agensi ini ialah Jabatan Perkhidmatan Awam Malaysia (JPA), Kementerian Kewangan (MOF), Unit Penyelarasan dan Pelaksanaan (ICU), Kementerian Hal Ehwal Ekonomi (MEA) dan Unit Pemodenan Tadbiran dan Perancangan Pengurusan Malaysia (MAMPU). Strategi penyelidikan ini ialah kaedah kaji selidik dan membenarkan pengkaji untuk menggunakan kaedah keratan rentas bagi mengumpulkan borang soal selidik di organisasi kajian. Prosedur pengumpulan data ini amat berguna untuk mengumpulkan data yang tepat, relevan, kurang bias dan berkualiti (Creswell, 2015; Sekaran \& Bougie, 2016). Langkah pertama dalam pengumpulan data, pengkaji telah menyediakan borang soal selidik berdasarkan kajian literatur yang berkaitan dengan bimbingan penyelia. Seterusnya, teknik terjemahan balik seperti yang disyorkan oleh Wright, (1996) telah digunakan untuk menterjemah soalan soal selidik ke bahasa Melayu dan bahasa Inggeris. Pihak yang terlibat dalam proses penterjemahan ini ialah seorang pensyarah bahasa Inggeris, seorang pensyarah bahasa Melayu dan dua orang pensyarah dalam bidang pengurusan di Universiti Kebangsaan Malaysia (UKM). Pelaksanaan teknik penterjemahan ini diharapkan dapat memastikan ketepatan dan kebolehpercayaan instrumen kajian.

\section{Alat Pengukuran}

Borang soal selidik kajian ini mengandungi tiga bahagian: Pertama, bimbingan penyelia dinilai berdasarkan tujuh item yang diadaptasikan daripada kajian literatur berkaitan dengan bimbingan penyelia dalam program latihan (Tharenou, 2001; Burke \& Badwin, 1999). Bimbingan penyelia dinilai berdasarkan dua dimensi iaitu tunjuk ajar dan maklum balas. Kedua, motivasi pembelajaran dinilai berdasarkan 5 item yang diadaptasikan daripada kajian literatur yang berkaitan dengan pembelajaran organisasi (Machin \& Treloar, 2004; Kim-Soon \& Ahmad, 2012). Motivasi pembelajaran dinilai berdasarkan dua dimensi iaitu keinginan mempelajari latihan dan manfaat latihan. Ketiga, motivasi kerja dinilai berdasarkan 5 item yang diadaptasikan daripada kajian literatur berkaitan dengan 
motivasi kerja (Podsakoff, Ahearne \& MacKenzie, 1997; Wallace, Chernatony \& Buil, 2011). Motivasi kerja dinilai berdasarkan dua dimensi iaitu dorongan melaksanakan tugas hakiki dan tugas sampingan. Kesemua item tersebut telah dinilai mengikut skala jawapan 7 pilihan, iaitu bermula daripada "sangat tidak setuju/ sangat tidak puas hati" (1) hingga "sangat setuju/sangat puas hati" (7). Secara khususnya, skala pengukuran ini dipilih dalam kajian ini kerana berupaya meningkatkan kebolehpercayaan yang optimum dalam menilai reaksi responden (Lewis, 1993), menghasilkan tindak balas secara neutral dan lebih baik (Cox, 1980). Ciri-ciri demografi responden telah digunakan sebagai pemboleh ubah kawalan kerana kajian ini hanya menumpukan kepada sikap pekerja.

\section{Sampel Kajian}

Unit analisis kajian ini ialah pekerja yang sedang berkhidmat di organisasi kajian. Teknik pensampelan bertujuan telah digunakan untuk mengedarkan 300 keping borang soal selidik kepada pekerja yang terdiri daripada perbagai peringkat dan kategori perjawatan di bahagian/jabatan yang berlainan dalam organisasi kajian. Secara khususnya, teknik pensampelan ini dipilih kerana pihak pengurusan organisasi tidak dapat memberikan senarai pekerja yang lengkap atas alasan sulit dan ingin menjaga reputasi serta imej korporat organisasi. Oleh itu, keadaan ini tidak mengizinkan pengkaji menggunakan kaedah rawak untuk memilih responden kajian. Daripada jumlah borang soal selidik yang telah diedarkan, hanya 190 (63.3\%) borang yang dijawab dengan lengkap telah dikembalikan kepada pengkaji. Kesemua responden ini menjawab borang soal selidik ini dengan kerelaan dan tanpa paksaan. Seterusnya, jawapan bias dalam borang soal selidik telah disemak menggunakan ujian Harman's Single Factor seperti yang disyorkan oleh Padsakoff et al. (2003). Keputusan pengujian ini memaparkan bahawa nilai varian ialah 49 peratus, iaitu kurang daripada nilai 50 peratus (Padsakoff et al., 2003). Ini bermakna unsur bias ialah tidak kritikal dalam data borang soal selidik kajian ini.

\section{Dapatan Kajian}

\section{Analisis Kajian}

Jadual 1 menunjukkan bahawa kebanyakan responden berumur antara 34 tahun dengan 39 tahun (35.8\%), perempuan (63.2\%), berkelulusan 
ijazah sarjana muda (43.7\%), berkahwin (64.7\%), kumpulan perkhidmatan pelaksana/sokongan (63.2\%), berpendapatan bulanan RM1,000 hingga RM1,999 (70\%) dan tempoh berkhidmat daripada 11 tahun hingga 15 tahun $(31.6 \%)$.

Jadual 1

Ciri-ciri Responden Kajian ( $n=190)$

\begin{tabular}{|c|c|c|c|}
\hline Profil Responden & Sub-Profil & Kekerapan & Peratusan \\
\hline \multirow[t]{5}{*}{ Umur } & Kurang 27 tahun & 31 & 16.3 \\
\hline & 28 hingga 33 tahun & 39 & 20.5 \\
\hline & 34 hingga 39 tahun & 68 & 35.8 \\
\hline & 40 hingga 45 tahun & 31 & 16.3 \\
\hline & Lebih 46 tahun & 21 & 11.1 \\
\hline \multirow[t]{2}{*}{ Jantina } & Lelaki & 64 & 63.2 \\
\hline & Perempuan & 126 & 36.8 \\
\hline Taraf Pendidikan & PMR & 2 & 1.1 \\
\hline \multirow[t]{5}{*}{ Tertinggi } & SPM & 31 & 16.3 \\
\hline & Diploma/ SPTM & 41 & 21.6 \\
\hline & Ijazah Sarjana Muda & 83 & 43.7 \\
\hline & Sarjana & 28 & 14.7 \\
\hline & Doktor Falsafah & 5 & 2.6 \\
\hline \multirow[t]{3}{*}{ Taraf Perkahwinan } & Bujang & 62 & 32.6 \\
\hline & Berkahwin & 123 & 64.7 \\
\hline & Duda/Janda & 5 & 2.6 \\
\hline Kumpulan & Kumpulan Pelaksana/ & 120 & 63.2 \\
\hline \multirow[t]{2}{*}{ Perkhidmatan } & Sokongan & 70 & 36.8 \\
\hline & $\begin{array}{l}\text { Kumpulan Pengurusan } \\
\text { dan Profesional }\end{array}$ & & \\
\hline Gaji Termasuk Elaun & RM1000 hingga RM1999 & 133 & 70.0 \\
\hline \multirow[t]{3}{*}{ Tetap } & RM2000 hingga RM2999 & 43 & 22.6 \\
\hline & RM3000hingga RM3999 & 13 & 6.8 \\
\hline & RM4000 hingga RM4999 & 1 & .5 \\
\hline \multirow[t]{4}{*}{ Tempoh Perkhidmatan } & Kurang 5 tahun & 50 & 26.3 \\
\hline & 6 hingga 10 tahun & 50 & 27.3 \\
\hline & 11 hingga 15 tahun & 60 & 31.6 \\
\hline & Lebih 16 tahun & 30 & 15.8 \\
\hline
\end{tabular}

Nota: PMR (Penilaian Menengah Rendah)

SPM (Sijil Penilaian Menengah)

STPM (Sijil Tinggi Pelajaran Malaysia) 


\section{Analisis Kesahan dan Kebolehpercayaan Instrumen}

Jadual 2 menunjukkan analisis kesahan konvergen. Korelasi antara item dengan konstruk mempunyai nilai pemberat lebih besar daripada 0.70 dan kesemua konstruk mempunyai nilai varian purata di ekstrak (AVE) lebih besar daripada 0.50 (Hair, Hult, Ringle \& Sarstedt, 2017). Sebaliknya, nilai kebolehpercayaan komposit bagi setiap konstruk adalah melebihi 0.80 (Hair et al., 2017) bermaksud semua konstruk kajian mempunyai tahap kebolehpercayaan yang tinggi. Dapatan ini menerangkan bahawa konstruk kajian ini telah mematuhi piawai kesahan konvergen yang ditetapkan.

Jadual 2

Ujian Kesahan Konvergen dan AVE

\begin{tabular}{|c|c|c|c|}
\hline Konstruk & $\begin{array}{l}\text { Nilai } \\
\text { pemberat }\end{array}$ & AVE & $\begin{array}{l}\text { Kebolehpercayaan } \\
\text { komposit }\end{array}$ \\
\hline Bimbingan Penyelia & & 0.69 & 0.94 \\
\hline $\begin{array}{l}\text { A1: memberikan pertolongan } \\
\text { untuk mengaplikasikan } \\
\text { kemahiran baru }\end{array}$ & 0.83 & & \\
\hline $\begin{array}{l}\text { A2: mencadangkan kaedah } \\
\text { mengaplikasikan latihan }\end{array}$ & 0.84 & & \\
\hline $\begin{array}{l}\text { A3: mencadangkan masa yang } \\
\text { cukup untuk mempraktikkan } \\
\text { kemahiran baru }\end{array}$ & 0.82 & & \\
\hline $\begin{array}{l}\text { A4: mendorong untuk } \\
\text { mengaplikasikan pendekatan } \\
\text { baru }\end{array}$ & 0.83 & & \\
\hline $\begin{array}{l}\text { A5: melaporkan prestasi terkini } \\
\text { apabila menggunakan } \\
\text { kemahiran baru }\end{array}$ & 0.84 & & \\
\hline $\begin{array}{l}\text { A6: memberikan pandangan positif } \\
\text { terhadap prestasi }\end{array}$ & 0.83 & & \\
\hline $\begin{array}{r}\text { A7: menetapkan matlamat untuk } \\
\text { mengaplikasikan kemahiran }\end{array}$ & 0.83 & & \\
\hline Motivasi Pembelajaran & & 0.65 & 0.90 \\
\hline $\begin{array}{l}\text { B1: bersemangat untuk } \\
\text { mempelajari kemahiran }\end{array}$ & 0.81 & & \\
\hline
\end{tabular}

(continued) 
IJMS 26(2), 99-124 (2019)

\begin{tabular}{|c|c|c|c|}
\hline Konstruk & $\begin{array}{l}\text { Nilai } \\
\text { pemberat }\end{array}$ & AVE & $\begin{array}{l}\text { Kebolehpercayaan } \\
\text { komposit }\end{array}$ \\
\hline $\begin{array}{l}\text { B2: berminat untuk menghadiri } \\
\text { program latihan }\end{array}$ & 0.82 & & \\
\hline $\begin{array}{l}\text { B3: memberikan tumpuan } \\
\text { sepenuhnya dalam program } \\
\text { latihan }\end{array}$ & 0.73 & & \\
\hline $\begin{array}{l}\text { B4: meningkatkan motivasi } \\
\text { melaksanakan tugas }\end{array}$ & 0.82 & & \\
\hline $\begin{array}{c}\text { B5: meningkatkan usaha untuk } \\
\text { bekerja dengan efisien }\end{array}$ & 0.84 & & \\
\hline Motivasi Kerja & & 0.70 & 0.92 \\
\hline $\begin{array}{l}\text { C1: bersedia membantu rakan } \\
\text { sekerja dalam tugas }\end{array}$ & 0.87 & & \\
\hline $\begin{array}{l}\text { C2: terdorong membantu rakan } \\
\text { menyelesaikan tugas }\end{array}$ & 0.88 & & \\
\hline $\begin{array}{l}\text { C3: mengambil bahagian dalam } \\
\text { mesyuarat }\end{array}$ & 0.75 & & \\
\hline $\begin{array}{l}\text { C4: yakin hasil kerja lebih } \\
\text { berkualiti }\end{array}$ & 0.83 & & \\
\hline $\begin{array}{l}\text { C5: boleh mengembangkan } \\
\text { kemahiran yang dipelajari }\end{array}$ & 0.84 & & \\
\hline
\end{tabular}

Jadual 3

Ujian Kesahan Diskriminan

\begin{tabular}{lcc}
\hline Konstruk & Bimbingan Penyelia & Motivasi Pembelajaran \\
\hline Bimbingan Penyelia & & \\
Motivasi Pembelajaran & 0.65 & \\
& $(0.46-0.70)$ & 0.74 \\
Motivasi Kerja & 0.60 & \\
& $(0.46-0.70)$ & \\
\hline
\end{tabular}

Nota: Dalam kurungan ialah nilai-nilai selang keyakinan bagi setiap konstruk kajian $(25 \%, 97.5 \%)$

Jadual 3 memaparkan tahap kesahan diskriminan. Nilai heterotraitmonotrait ratio (HTMT) bagi setiap konstruk kajian adalah kurang 
daripada 0.85 , manakala nilai selang keyakinan yang terdapat dalam kurungan bagi setiap konstruk ini adalah kurang daripada nilai 1, bererti semua konstruk kajian ini telah memenuhi tahap kesahan diskriminan yang telah ditetapkan (Hair et al., 2017).

\section{Analisis Konstruk}

Jadual 4 memaparkan dapatan ujian statististik asas dan analisis korelasi pearson. Nilai min bagi semua konstruk kajian bermula daripada 5.75 hingga 5.98, bermaksud bimbingan penyelia, motivasi pembelajaran dan motivasi kerja berada antara tahap tinggi (4) dan sangat tinggi (7). Sebaliknya, korelasi antara a) bimbingan penyelia dengan motivasi kerja dan b) bimbingan penyelia dengan motivasi pembelajaran mempunyai nilai faktor inflasi varian (VIF) yang kurang daripada 5.0 (Hair et al., 2017) bermakna semua kontruk kajian tidak mempunyai masalah kolineariti yang kritikal.

Jadual 4

Dapatan Ujian Statistik Asas dan Faktor Inflasi Varian

\begin{tabular}{|c|c|c|c|c|}
\hline \multirow[t]{2}{*}{ Konstruk } & \multicolumn{2}{|c|}{ Nilai Inflasi Varian } & \multirow[t]{2}{*}{ Min } & \multirow[t]{2}{*}{ Sisihan Piawai } \\
\hline & $\begin{array}{c}\text { Motivasi } \\
\text { Pembelajaran }\end{array}$ & $\begin{array}{c}\text { Motivasi } \\
\text { Kerja }\end{array}$ & & \\
\hline Bimbingan Penyelia & 1.00 & 1.52 & 5.75 & 0.72 \\
\hline Motivasi Pembelajaran & & 1.52 & 5.94 & 0.62 \\
\hline Motivasi Kerja & & & 5.98 & 0.63 \\
\hline
\end{tabular}

\section{Dapatan Pengujian}

Jadual 5 menunjukkan bahawa bimbingan penyelia menyumbang sebanyak 24 peratus kepada perubahan dalam motivasi kerja, nilai ini adalah kurang daripada 33 peratus bererti model mempunyai kesan yang sederhana. Sebaliknya, bimbingan penyelia menyumbang sebanyak 58 peratus perubahan dalam motivasi pembelajaran, nilai ini lebih daripada 33 peratus bermaksud model mempunyai kesan yang besar. Manakala, bimbingan penyelia dan motivasi pembelajaran menyumbang sebanyak 51 peratus perubahan dalam motivasi kerja, nilai ini lebih besar daripada 33 peratus, bermakna model mempunyai kesan yang besar (Cohen, 1989). Seterusnya, 
dapatan pengujian hipotesis menunjukkan tiga penemuan penting: Pertama, hubungan antara bimbingan penyelia dan motivasi kerja adalah signifikan $(\beta=0.27 ; \mathrm{t}=3.30)$, oleh itu $\mathrm{H}_{1}$ disokong. Kedua, hubungan antara bimbingan penyelia dan motivasi pembelajaran adalah signifikan $(\beta=0.35 ; \mathrm{t}=3.78)$, oleh itu $\mathrm{H}_{2}$ disokong. Ketiga, hubungan antara bimbingan penyelia, motivasi pembelajaran dan motivasi kerja adalah signifikan $(\beta=0.17 ; \mathrm{t}=2.065)$, oleh itu $\mathrm{H}_{3}$ disokong. Dapatan ini menegaskan bahawa bimbingan penyelia adalah pemboleh ubah peramal yang penting kepada motivasi kerja dan motivasi pembelajaran. Manakala, kesan bimbingan penyelia ke atas motivasi kerja dipengaruhi secara tidak langsung oleh motivasi pembelajaran.

Jadual 5

Dapatan Pengujian Hipotesis $\mathrm{H}_{1} \mathrm{H}_{2}$ dan $\mathrm{H}_{3}$

\begin{tabular}{|c|c|c|c|c|c|c|}
\hline Hipotesis & Hubungan & $R^{2}$ & Keputusan & Nilai $\beta$ & $\begin{array}{c}\text { Nilai } \\
t\end{array}$ & Keputusan \\
\hline $\mathrm{H}_{1}$ & $\begin{array}{l}\text { Bimbingan Penyelia } \longrightarrow \\
\text { Motivasi Kerja }\end{array}$ & $24 \%$ & $\begin{array}{c}\text { Kesan } \\
\text { yang } \\
\text { sederhana }\end{array}$ & 0.27 & 3.30 & Disokong \\
\hline $\mathrm{H}_{2}$ & $\begin{array}{l}\text { Bimbingan Penyelia } \longrightarrow \\
\text { Motivasi Pembelajaran }\end{array}$ & $58 \%$ & $\begin{array}{c}\text { Kesan } \\
\text { yang besar }\end{array}$ & 0.35 & 3.78 & Disokong \\
\hline $\mathrm{H}_{3}$ & $\begin{array}{l}\text { Bimbingan Penyelia } \longrightarrow \\
\text { Motivasi Pembelajaran } \longrightarrow \\
\text { Motivasi Kerja }\end{array}$ & $51 \%$ & $\begin{array}{c}\text { Kesan } \\
\text { yang besar }\end{array}$ & 0.17 & 2.065 & Disokong \\
\hline
\end{tabular}

Selanjutnya ujian kesepadanan model, saiz kesan konstruk, ketepatan jangkaan, didapati jenis kesan pemboleh ubah pengantara dan peramalan prestasi telah dilaksanakan berdasarkan prosedur bootstrapping dan blindfolding. Keputusan ujian kesepadanan model kajian menunjukkan bahawa nilai estimated root mean square residual (SRMR) ialah 0.07, iaitu kurang daripada 0.08 (Hu \& Bentler, 1999), bermakna model kajian ini adalah sesuai. Manakala, keputusan ujian saiz kesan konstruk menghasilkan tiga penemuan penting: Pertama, hubungan antara bimbingan penyelia dan motivasi kerja mempunyai nilai $f^{2} 0.52$, iaitu lebih besar daripada 0.35 (Cohen, 1988), bermakna kesan bimbingan penyelia terhadap motivasi kerja adalah besar. Kedua, hubungan antara bimbingan penyelia dan motivasi pembelajaran mempunyai nilai $f^{2} 0.07$, iaitu lebih kecil daripada 0.15 
(Cohen, 1988), bererti kesan bimbingan penyelia terhadap motivasi pembelajaran adalah kecil. Ketiga, hubungan antara motivasi pembelajaran dan motivasi kerja mempunyai nilai $f$ 0.33, iaitu lebih kecil daripada 0.35 (Cohen, 1988), bermakna kesan motivasi pembelajaran ke atas motivasi pembelajaran adalah sederhana.

Selain itu, keputusan ujian jenis kesan pemboleh ubah pengantara menunjukkan bahawa motivasi pembelajaran berupaya bertindak sebagai pemboleh ubah pengantara separa dalam perhubungan antara bimbingan penyelia dengan motivasi kerja. Di samping itu, keputusan ujian ketepatan jangkaan menghasilkan dua penemuan penting: Pertama, nilai $Q^{2}$ bagi motivasi kerja ialah 0.30 dan motivasi kerja ialah 0.20. Nilai-nilai ini adalah lebih besar daripada sifar, bererti konstruk tersebut telah mencapai tahap ketepatan ramalan yang ditetapkan (Hair et al., 2017). Seterusnya, ujian peramalan prestasi model dilaksanakan mengguna PLS Predict. Jadual 6 menunjukkan bahawa jumlah nilai positif dan negatif adalah sama banyak dalam analisis PLS-SEM root mean square error (RMSE) dan linear regression model (LM), bermakna model kajian ini mencapai tahap kebolehupayaan ramalan yang sederhana (Shmueli, Ray, Velasquez Estrada, 2016).

Jadual 6

Dapatan Analisis PLS Predict bagi Penilaian Pemboleh Ubah

\begin{tabular}{lccll}
\hline Item & $\begin{array}{c}\text { PLS SEM } \\
\text { RMSE }\end{array}$ & $\begin{array}{c}\text { LM } \\
\text { RMSE }\end{array}$ & $\begin{array}{c}\text { LM-PLS } \\
\text { SEM RMSE }\end{array}$ & $\begin{array}{l}\text { PLS SEM } \\
\text { RMSE-LM }\end{array}$ \\
\hline B1 & 0.65 & 0.65 & 0 & 0 \\
B2 & 0.69 & 0.69 & 0 & 0 \\
B3 & 0.72 & 0.71 & -0.01 & 0.01 \\
B4 & 0.70 & 0.70 & 0 & 0 \\
B5 & 0.66 & 0.70 & 0.04 & -0.04 \\
C1 & 0.68 & 0.66 & -0.02 & 0.02 \\
C2 & 0.68 & 0.68 & 0 & 0 \\
C3 & 0.71 & 0.72 & 0.01 & -0.01 \\
C4 & 0.65 & 0.64 & -0.01 & 0.01 \\
C5 & 0.68 & 0.70 & 0.02 & -0.02 \\
\hline
\end{tabular}

Nota:

PLS RMSE ialah root squared error dalam model PLS.

LM ialah linear regression dalam model linear. 


\section{Perbincangan dan Implikasi}

Dapatan kajian ini menunjukkan bahawa motivasi pembelajaran berupaya bertindak sebagai pemboleh ubah perantara yang penting dalam perhubungan antara bimbingan penyelia dengan motivasi kerja. Dalam konteks kajian ini, kebanyakan responden berpendapat bahawa tahap bimbingan penyelia, motivasi pembelajaran dan motivasi kerja adalah tinggi. Situasi ini menerangkan bahawa keupayaan penyelia mengamalkan tunjuk ajar dan menyampaikan maklum balas secara teratur akan membantu motivasi pekerja untuk menghadiri dan mempelajari pengetahuan yang penting, kemahiran yang terkini, kebolehan kognitif dan emosi yang baharu, sikap yang positif dan kebolehan-kebolehan semasa yang sesuai dengan revolusi industri 4.0. Natijahnya, keadaan ini boleh pula meningkatkan motivasi kerja dalam organisasi kajian.

Kajian ini menyumbang kepada tiga implikasi penting iaitu sumbangan terhadap teori, sumbangan terhadap pemantapan kaedah kajian dan sumbangan terhadap majikan. Sumbangan terhadap teori, penemuan kajian ini adalah konsisten dengan saranan utama yang dikemukakan oleh Teori Pembelajaran Sosial (Bandura, 1979), yang menerangkan bahawa keupayaan penyelia mengamalkan bimbingan yang baik dalam melatih pekerja semasa melaksanakan tugas harian melalui tunjuk ajar (seperti komunikasi, kerja berpasukan, memberikan peluang) dan maklum balas (seperti memberikan idea, memaklumkan prestasi, memberikan komen membina) akan dapat membantu meningkatkan motivasi pembelajaran pekerja (seperti bersemangat mempelajari kandungan latihan, memberikan tumpuan dalam latihan, komited memperbaharui kemahiran terkini). Seterusnya, tahap motivasi ini boleh pula mendorong pekerja meningkatkan motivasi kerja dalam organisasi. Saranan utama teori ini adalah menyokong dan menyebarluaskan kajian-kajian yang dilaksanakan oleh Utrilla et al. (2012); Nadeem dan Ahmad (2017); Park et al. (2018); Govaerts et al. (2017); Schindler \& Bukholder (2014); Kim et al. (2019).

Berhubung dengan sumbangan terhadap pemantapan kaedah penyelidikan, skala pengukuran dalam borang soal selidik kajian ini telah memenuhi piawai kesahan dan kebolehpercayaan yang ditetapkan. Pencapaian ini boleh menghasilkan dapatan yang tepat dan boleh dipercayai. 
Seterusnya, berdasarkan kepada sumbangan terhadap majikan, hasil kajian ini boleh digunakan sebagai panduan oleh pengamal untuk meningkatkan keberkesanan program latihan dalam organisasi. Cadangan penambahbaikan yang pertama ialah berdasarkan keputusan peta analisis kepentingan-prestasi (importance-performance map analysis, IPMA) seperti yang disyorkan oleh Ringle dan Sarstedt (2016) boleh digunakan untuk mengenal pasti tindakan keutamaan bagi menyelesaikan permasalahan latihan organisasi. Jadual 7 menerangkan bahawa konstruk motivasi pembelajaran dianggap paling penting (nilai 0.53) dan paling tinggi menyumbang kepada prestasi motivasi kerja (nilai 82.48). Sebaliknya, konstruk bimbingan penyelia pula dianggap tidak penting (nilai 0.22) dan lemah dalam menyumbang kepada prestasi motivasi kerja (79.25). Konstruk ini perlu diberi perhatian sewajarnya bagi menambah baik program latihan dalam organisasi kajian.

Jadual 7

Dapatan Analisis IPMA

\begin{tabular}{lcc}
\hline \multicolumn{1}{c}{ Konstruk } & \multicolumn{2}{c}{ Motivasi Kerja } \\
& $\begin{array}{c}\text { Kepentingan } \\
\text { (Jumlah Kesan) }\end{array}$ & $\begin{array}{c}\text { Prestasi } \\
\text { (Nilai Index) }\end{array}$ \\
\hline Bimbingan Penyelia & 0.22 & 79.25 \\
Motivasi Pembelajaran & 0.53 & 82.48 \\
\hline
\end{tabular}

Antara langkah penambahbaikan yang perlu dilakukan ialah dengan menyediakan latihan profesional kepada penyelia untuk mendapat persijilan profesional sebagai jurulatih, mentor atau/dan kaunselor. Pihak pengurusan juga perlu memberi galakkan dan dorongan kepada penyelia untuk mengamalkan etika pengurusan yang berlandaskan nilai-nilai murni dalam perhubungan dengan staf pelaksana untuk melaksanakan tugasan secara berpasukan. Selain itu, penyelia perlu belajar memahami dan mengamalkan sistem interaksi berkualiti dalam penyampaian perkhidmatan, seperti mengambil peduli kebajikan dan masalah pekerja, memberi maklum balas terhadap aduan dan cadangan pekerja dan menunaikan janji dalam memenuhi kehendak dan pengharapan pekerja. Cadangan penambahbaikan di atas perlu diberi perhatian yang sewajarnya untuk mendorong 
pekerja mempelajari teknik baharu dalam menunaikan tugas dan tanggungjawab kerja harian. Seterusnya, keadaan ini boleh membantu mencapai dan mengekalkan objektif dan strategi organisasi dalam era globalisasi dan ekonomi berasaskan pengetahuan profesional.

\section{Kesimpulan}

Kajian ini menguji kerangka konseptual yang dibina berdasarkan kajian literatur yang berkaitan dengan program latihan. Skala pengukuran kajian ini telah memenuhi piawaian kesahan dan kebolehpercayaan yang ditetapkan. Dapatan pengujian hipotesis menggunakan SmartPLS mendedahkan bahawa motivasi pembelajaran berupaya bertindak sebagai pemboleh ubah pengantara yang penting dalam perhubungan antara bimbingan penyelia dan motivasi kerja. Dapatan ini telah menyokong dan menyebar luas kajian terdahulu yang diterbitkan di negara-negara Barat dan Asia. Oleh itu, kajian dan amalan baharu dalam latihan organisasi menyarankan bahawa motivasi pembelajaran perlu diambil kira sebagai elemen yang penting dalam domain bimbingan penyelia. Selanjutnya, kajian turut mencadangkan bahawa keupayaan penyelia mengamalkan bimbingan yang teratur dalam melaksanakan tugas dan tanggungjawab kerja harian akan dapat mendorong perubahan sikap dan kelakuan pekerja yang positif (seperti kepuasan, komitmen, etika dan kualiti). Justeru, keadaan yang positif ini boleh meningkatkan prestasi organisasi dalam era persaingan global yang sukar diramalkan.

Kajian ini mempunyai beberapa batasan konseptual dan metodologi. Pertama, kaedah keratan rentas hanya menggambarkan persepsi responden secara umun sahaja terhadap perhubungan antara pembolehubah kajian. Kedua, kajian ini tidak mengukur perhubungan antara dimensi bagi pemboleh ubah tidak bersandar, pemboleh ubah pengantara dan pemboleh ubah bersandar. Ketiga, teknik pensampelan bertujuan tidak berupaya mengawal jawapan bias responden kajian. Keempat, kajian ini hanya dijalankan di ibu pejabatibu pejabat Agensi Pusat Kerajaan Persekutuan Malaysia. Batasan di atas boleh mengurangkan keupayaan untuk menggeneralisasikan dapatan kajian ini kepada organisasi yang lain.

Kajian ini mengemukakan beberapa cadangan penambahbaikan untuk memantapkan penambahbaikan. Pertama, ciri-ciri responden 
yang penting seperti jantina, umur dan kumpulan perkhidmatan perlu diambil kira dalam kajian kerana dapat meramalkan persamaan dan perbezaan tanggapan responden terhadap model kajian. Keduanya, wajar mengaplikasikan kaedah perbandingan untuk menyukat keberkesanan motivasi pembelajaran sebagai pemboleh ubah pengantara yang berkesan dalam organisasi awam dan swasta. Ketiga, saiz sampel yang lebih besar perlu diambil kerana boleh mewakili populasi kajian. Keempat, dimensi bimbingan penyelia yang khusus seperti sokongan instrumental perlu dititik beratkan kerana elemen ini menjadi topik perbincangan yang hangat dalam kajian literatur yang berkaitan dengan latihan organisasi. Akhir sekali, ciri-ciri motivasi kerja yang khusus perlu diterokai seperti tugas sampingan dan hakiki yang merupakan natijah penting daripada perhubungan yang berlaku antara bimbingan penyelia dengan motivasi pembelajaran dalam organisasi berteraskan pengetahuan. Oleh itu, saranan di atas perlu diberi pertimbangan yang sewajarnya bagi menambah baik kajian masa hadapan.

\section{Penghargaan}

Kajian ini tidak menerima geran penyelidikan khusus daripada agensi awam, perniagaan atau bukan berorientasi keuntungan.

\section{Rujukan}

Abdullah Lin., Gunalan a/l Nadarajah., Mohmad Yazam Sharif., Abul Bashar Bhuiyan., \& Md. Aminul Islam (2015). The factors that affect the effectiveness of training: A Study at silterra

Malaysia Sdn. Bhd. A semiconductor company in Malaysia. International Journal of Management Studies, 22(Special Issues), 33-46.

Abu Alsondos, I., Pangil, F., \& Othman, S. Z. (2015). An empirical study on the effect of individual factors on tacit knowledgesharing in the ICT sector. International Journal of Management Studies, 22(2), 1-16.

Al-Eisa, A. K., Abdulla, F., \& Alhemoud, A. (2009). An empirical examination of the effects of self-efficacy, supervisor support and motivation to learn on transfer intention. Management Decision, 47, 1221-244. 
Bandura, A. (1979). Social learning theory. Englewood Cliffs, NJ: Prentice Hall.

Blau P. M. (1964). Exchange and power in social life. New Brunswick, NJ: Transaction Publishers.

Burke, L. A., \& Baldwin, T. T. (1999). Workforce training transfer: A study of the effect of relapse prevention training and transfer climate. Human Resource Management, 38, 227-242.

Cohen, J. (1992). A power primer. Psychological Bulletin, 112, 155-159.

Cox, E. P. (1980). The optimal number of response alternatives for a scale: A review. Journal of Marketing Research, 17(4), 407-422.

Creswell, J. W. (2015). Research design: qualitative, quantitative and mixed methods approaches (4th ed.). California: SAGE Publications.

Dansereau, F., Graen, G., \& Haga, W. J. (1975). A vertical dyad linkage approach to leadership within formal organizations: A longitudinal investigation of the role making process. Organizational Behavior and Human Performance, 13, 46-78.

EL Hajjar, S. T., \& Alkhanaizi, M. S. (2018). Exploring the factors that affect employee training effectiveness: A case study in Bahrain. Capaian daripada https://us.sagepub.com/en-us/nam/openaccess-at-sage

Govaerts, N., Eva, K., \& Filip, D. (2017). The influence of specific supervisor support types on transfer of training: Examining the mediating effect of training retention. Vocation and Learning, $11,265-288$.

Hair, J. F., Hult, G. T. M., Ringle, C. M., \& Sarstedt, M. (2017). A Primer on Partial Least Squares Structural Equation Modeling (PLS-SEM) (2nd ed.). Los Angeles: SAGE Publications.

Hee, O. C., \& Rhung, L. X. (2019). Motivation and employee retention among millennials in Malaysia. International Journal of Academic Research in Business and Social Sciences, 9(2), 876-884.

Hu, L. T., \& Bentler, P. M. (1999). Cut off criteria for fit indexes in covariance structure analysis: Conventional criteria versus new alternatives. Structural Equation Modeling, 6, 1-55.

Hussien, T. (2009). Malaysia negara kita. Kuala Lumpur, Malaysia: MDC Publishers.

Ibrahim, S. (2007). Malaysia kita. Panduan dan rujukan untuk peperiksaan am kerajaan. Kuala Lumpur: International Law Book Services.

Ismail, A., Mohd Zainol, N. A., \& Ahmad, N. N. (2016). Program pembangunan kepimpinan meningkatkan pemindahan latihan dalam tentera darat Malaysia: Kajian empirikal. Jurnal Pengurusan, 46, 149-161. 
Jabatan Perkhidmatan Awam. (2019). Dicapai daripada https://docs. jpa.gov.my/docs/pekeliling/pp05/bil06/PPbil06.pdf

Kanfer, R., Frese, M., \& Johnson, R. E. (2017). Motivation related to work: A century of progress. Journal of Applied Psychology, 102(3), 338-355.

Kim-Soon, N., \& Ahmad, N. (2012). Impact of motivation to learn on perceived training transfer: Empirical evidence from a bank. Proceedings International Conference of Technology Management, Business and Entrepreneurship. Renaissance Hotel, Melaka, Malaysia.

Kim, S., \& Kuo, M. H. (2015). Examining the relationships among coaching, trustworthiness, and role behaviors: A social exchange perspective. The Journal of Applied Behavioral Science 51(2), 152-176.

Kim, E. J., Park, S., \& Kang, H. S. (2019). Support, training readiness and learning motivation in determining intention to transfer. European Journal of Training and Development, 43(No. 3/4), 306321.

Lee, J. Y., Park, S., \& Baker, R. (2017). The moderating role of top management support on employees' attitudes in response to human resource development efforts. Journal of Management $\mathcal{E}$ Organization, 24, 369-387.

Lewis, J. R. (1993). Multipoint scales: Mean and median differences and observed significance levels. International of HumanComputer Interaction, 5(4), 383-392.

Machin, M. A., \& Treloar, C. A. (2004). Predictors of motivation to learn when training is mandatory. Proceedings of the 39th Australian PsychologicalSociety Annual Conference:PsychologicalScience in Action. Dicapai daripada https://pdfs.semanticscholar.org

Musa, K. (2020). Mantapkan integriti perkhidmatan awam Dicapai daripada http://www.bhplus.com.my rencana muka10/2018/11/498223/mantapkan-integriti-perkhidmatanawam

Nadeem, K., \& Ahmad, A. (2017). Impact of work environment factors on employee performance: Empirical evidence from manufacturing industry of Lahore. Journal of Managerial Sciences, 11, 422-436.

Ospina, S., El Hadidy, W., \& Caicedo, G. (2011). Advancing diversity and inclusion in public service: A review of leadership development programs in the US. Dicapai daripada https://wagner.nyu.edu/ leadership/theory/diversity 
Park, S., Kang, H. S., \& Kim, E. J. (2018). Does supervisor support make a difference in employees'training and job performance? An empirical study of a professional development p rog r a m . European Journal of Training and Development, 1-29.

Pekeliling kemajuan pentadbiran awam myportfolio (2018): Panduan kerja sektor awam (4). Retrieved from https://www. parlimen.gov.my/images/webuser/pengumuman/PKPA $\% 20$ BIL.4_2018myportfolio\%20Panduan\%20Kerja\%20Sektor\%20 Awam-JD-JOB\%20DESCRIPTION.pdf

Podsakoff, P. M., Ahearne, M., \& MacKenzie, S., B. (1997). Organizational citizenship behavior and the quantity and quality of work group performance. Journal of Applied Psychology, 8, 262-270.

Portefract, D. The Wasted Dollors of Corporate Training Programs. (2019). Dicapai daripada https://www.forbes. $\mathrm{com} / \# 71856 \mathrm{a} 4 \mathrm{a} 2254$

Roblek, V., Erenda, I., \& Meško, M. (2018). The challenges of sustainable business development in the post-industrial society in the first half of the 21st century. In Managerial Strategies for Business Sustainability During Turbulent Times: IGI Global.

Ringle, C. M., \& Sarstedt, M. (2016). Gain more insight from your PLSSEM results: The importance-performance map analysis. Industrial Management \& Data Systems, 116, 1865- 1886.

Schindler, L. A., \& Bukholders, G., J. (2014). A mixed methods examination of the influence of dimensions of support on training transfer. Journal of Mixed Methods Research, 10, 1-19.

Sekaran, U., \& Bougie, R. (2016). Research methods for business: A skill building approach (7th ed.). United Kingdom: John Wiley \& Sons.

Shmueli, G., Ray, S., Velasquez Estrada, J. M. (2016). The elephant in the room: Evaluating the predictive performance of PLS Models. Journal of Business Research, 69, 4552-4564.

Thareou, P. (2001). The relationship of training motivation to participation in training and development. Journal of Occupational and Organizational Psychology, 74, 599-621.

Turner, J. R., \& Baker, R. (2017). Pedagogy, leadership, and leadership development. Performance Improvement, 56, 5-11.

Utrilla, P. N. C., Grande, F. A., \& Lorenzo, D. (2015). The effects of coaching in employees and organizational performance: The Spanish Case. Intangible Capital, 11, 166-189.

Wallace, E., \& Isabel, B. (2011). Within-role, extra-role and anti-role behaviours in retail banking. International Journal of Bank Marketing, 29, 470-488. 
IJMS 26(2), 99-124 (2019)

Wright, L. L. (1996). Qualitative international management research. In. Punnett, B. J. \& Shenkar, O. (Eds.), Handbook for International Management Research (pg. 23-45). Oxford: Blackwell Publishers. 